This is a self-archived - parallel published version of this article in the publication archive of the University of Vaasa. It might differ from the original.

\title{
Ensuring corporate travel compliance - Control vs. commitment Strategies
}

Author(s): Holma, Anne-Maria; Bask, Anu; Kauppi, Katri

Title: $\quad$ Ensuring corporate travel compliance - Control vs. commitment Strategies

Year: $\quad 2015$

Version: Accepted manuscript

Copyright (C) 2015 Elsevier. This manuscript version is made available under the Creative Commons Attribution-NonCommercial-NoDerivatives 4.0 International (CC BY-NC-ND 4.0) license, https://creativecommons.org/licenses/by-nc-nd/4.o/

Please cite the original version:

Holma, A-M., Bask, A. \& Kauppi, K. (2015). Ensuring corporate travel compliance - Control vs. commitment Strategies. Tourism

Management 51, 60-71.

http://dx.doi.org/10.1016/j.tourman.2015.04.008 


\title{
Tourism Management, Accepted manuscript
}

\section{ENSURING CORPORATE TRAVEL COMPLIANCE - CONTROL VS. COMMITMENT STRATEGIES}

\author{
Holma, Anne-Maria *, University of Vaasa, Department of Management, P.O.Box 700, 65101 Vaasa, \\ Finland. Email: anne-maria.holma@uva.fi \\ Bask, Anu, Aalto University School of Business, Department of Information and Service Economy, \\ Runeberginkatu 22-24, 00100 Helsinki, P.O. Box 21220, 00076 Aalto, Finland. Email: anu.bask@aalto.fi \\ Kauppi, Katri, Aalto University School of Business, Department of Information and Service Economy, \\ Runeberginkatu 22-24, 00100 Helsinki, P.O.Box 21220, 00076 Aalto, Finland. Email: \\ katri.kauppi@aalto.fi \\ * corresponding author
}

\begin{abstract}
Business travel has increased substantially during the past few decades. Business travel costs are one of the main controllable costs in international corporations, and thus companies are imposing stricter policies on corporate travel to create savings and efficiency. For travel management, the current literature suggests two alternative management strategies based on either a controloriented or a commitment-oriented approach. In this paper we present an in-depth case study that investigates the impact that each type of strategy has on corporate travel policy compliance. Specifically, we investigate how the strategies are executed in a triadic travel supply chain setting, consisting of a corporate travel buyer, a business travel agency and a technology provider. Our findings show that both the control and commitment-based strategies are used in all stages of the travel process. The seminal finding is that the competitiveness and high quality of services provided internally by the buyer in collaboration with the triad members - rather than strict control and monitoring - is essential to travel policy compliance. This finding shows that corporate travel management shares similar perspectives to leisure travel in that service quality is key to securing business. Furthermore, a proactive approach to control via a well-established and reasonable travel policy is needed.
\end{abstract}

Keywords: Corporate travel, control, commitment, travel policy compliance, service triad, service quality, case study.

Article classification: Research paper 
Acknowledgements: The authors thank the editor-in-chief and the anonymous reviewers for their constructive and helpful comments for developing the paper. The authors also are grateful to the participating organizations. 


\section{Introduction}

International travel for business purposes is an important component of international tourism, especially in economic terms. Industry reports reveal a strong connection between spending on business travel and corporate performance in terms of, for example, sales, customer retention, partnerships, innovation and human capital (World Travel and Tourism Council, 2011). Corporate travel purchases are typically part of an organization's indirect spend (i.e. spend that does not directly impact manufacturing processes) (Cuganesan \& Lee, 2006), to which many organizations are taking an increasingly structured approach (Cox, Watson, Lonsdale, \& Sanderson, 2004). Corporate travel is frequently seen as providing an opportunity to implement cost-cutting strategies (Anderson, Lewis, \& Parker, 1999; Aguilera, 2008) as it is generally estimated to be the second or third largest controllable cost after wages and IT (American Express \& A.T. Kearney, 2008). Adopting strict travel policies and channelling purchases to preferred suppliers are common ways to save in travel costs (Douglas \& Lubbe, 2010).

Despite the magnitude and importance of corporate travel spend, relatively little research has been focused on business travel (Morrison, Ladig, \& Hsieh, 1994), corporate travel purchases, and their management (Douglas \& Lubbe, 2009; Gustafson, 2012). Corporate travel management can be a challenging subject, however, as it involves not only the management of relationships between corporate buyers, travel agencies and suppliers (Douglas \& Lubbe, 2006; Holma, 2012), but also employee relationships and internal managerial control (Gustafson, 2013). Organizations have developed policies on service purchases and have a set of approved suppliers to business travel purchases. However, strict employee compliance is still necessary in order to fulfil established supplier contracts, and to benefit from purchasing synergies (Karjalainen, Kemppainen \& van Raaij, 2009). Yet when services are delivered to internal customers without the buyer's involvement ( $\mathrm{Li} \&$ Choi, 2009) - as is the case in business travel - a risk of noncompliance and challenges of control arise. Such non-compliance is indeed reported to be common in many organizations (Cox et al., 2004; Douglas \& Lubbe, 2009; 2010; Karjalainen et al., 2009). As there is only a limited amount of literature on policy compliance in the field of corporate travel (Gustafson, 2013), we will focus on corporate travel policy compliance and the degree to which the terms of centralized travel contracts are met.

Tourism, in general, is a coordination-intensive industry (Zhang, Song, \& Huang, 2009), and corporate travel, in particular, can only be managed well when there is close cooperation with the actors in the travel service supply chain. Various entities in the industry need to collaborate vertically, horizontally and diagonally to achieve competitiveness and provide quality services (March \& Wilkinson, 2009; Pansiri, 2008; Phat \& Milne, 2008). Although much research has been done on tourist industry relationships, most of it has focused on competitive interactions (Zhang et al., 2009), leaving scope for the study of coordination and cooperation in service delivery. Our study interest is on collaboration on the supply side of corporate travel. Purchasing in this setting is typified by triadic relationships, because there is generally a travel intermediary between the buyer and the suppliers (Gustafson, 2012; Holma, 2013). The aim of the study is to examine how triadic buyer-intermediary-supplier cooperation can enhance policy compliance in corporate travel purchases. Our triadic case, taken as a unit of analysis, allows us to investigate the co-operation, task allocation and use of resources between these actors. We will focus on two strategy types applicable to corporate travel management: control-oriented strategies and commitment-based strategies (Gustafson, 2013). We will study the approaches used under each strategy, their effectiveness, and how the triad actors cooperate in each strategy. 
Our main contribution relates to corporate travel management by providing a detailed account of control-oriented and commitment-based strategies and their execution. An important additional contribution is the study's triadic perspective, which provides new insights on how three-party cooperation can improve corporate travel management. Zhang et al.'s (2009) review of tourism supply chain management showed that most previous studies have focused only on two-party relationships. Taking the focal triad as the starting point, we analyse how the travel intermediary and its supplier are connected, directly or indirectly, to the buyer's travel management process. This is an important direction in travel management research, given the current situation in which networked structures and alliances are increasingly present in the field (Pansiri, 2008; Zhang et al., 2009). Our study also responds to the wider calls in management research to move beyond dyadic analyses to a more systemic and holistic understanding of networks (Buhman, Kekre, \& Singhal, 2005; Choi \& Kim, 2008; Harland, Brenchley, \& Walker, 2003; Shook, Adams, Ketchen, \& Craighead, 2009). Furthermore, our research contributes to tourism supply chain management, a currently understudied area (Topolšek, Mrnjavac, \& Kovačić, 2014; Zhang et al., 2009), by bridging literature from the travel management, human resources management, and purchasing and supply management fields in the corporate travel context.

The paper is structured as follows. The next section provides the theoretical background to the study. The third section explains the research methodology and introduces the focal triad and the case companies. The corporate travel purchaser in our study is a university. In the fourth section we will discuss the case study findings. Discussion and comparisons with previous findings in the literature are provided in section five. The final section concludes the study, and proposes avenues for further research.

\section{Theoretical background}

In this section, we will first discuss corporate travel purchasing and the most important actors involved. Then the two alternative strategies for travel policy compliance, control and commitment are discussed.

\subsection{Corporate travel purchasing and management}

Corporate travel can be defined as "travel undertaken by the employees of a particular organization that has a substantial travel volume and where travel arrangements are generally managed and consolidated into a centralized function" (Douglas \& Lubbe, 2006: 1131). It is a business consumption service (Wynstra, Axelsson, \& Van der Valk, 2006) that is often purchased in a centralized way and booked and used by the end-users. Corporate travel may be defined as a consumer service, as it is the individual consumer, the business traveller, who uses the service as a completed product. However, as such travel is undertaken for work-related reasons and is usually paid for by the employer, it could also be classified as a business service (Mason \& Gray, 1999; Bell \& Morey, 1997).

Corporate travel, as is typical of business consumption services, requires substantial administrative efforts and on-going interactions at several organizational levels (Wynstra et al., 2006), where both managerial and operational-level interactions are central (Holma, 2012). Travel services are contracted on the basis of competitive bidding at the managerial level (cf. Wynstra et al., 2006), whereas travel bookings and payments to suppliers, as well as payment of daily allowances to the employees, are handled at the operational level (Holma, 2012). 
Business travel markets involving many suppliers and different pricing practices challenge procurement routines and controls (Gustafson, 2013; Narangajavana, Garrigos-Simon, Garcia, \& Forgas-Coll, 2014). Therefore, it is important to engage internal sourcing professionals in service purchases for improved management and control of the services spend. Professional purchasers enable the development of better contracts and management of the service delivery process (Amaral, Billington, \& Tsay, 2004). Therefore many buying organizations have chosen to employ a corporate travel manager (Morrison et al, 1994), and to outsource the day-to-day travel management functions, such as bookings, to a business travel agency (Holma, 2012).

Corporate travellers generally use the resources of the preferred business travel agency and travel providers in their purchasing processes (Douglas \& Lubbe, 2006). Technology providers play an increasingly important role in travel purchasing and booking processes (Bigné, Aldás, Andreu, 2008). For example, in return for a fee, they offer access to travel providers' information via online Global Distribution Systems (GDSs) regarding the availability of airline seats and hotel rooms. Travel agencies access this information via dedicated connections (Lubbe \& Douglas, 2009). Today, corporate buyers are increasingly using online solutions developed either by traditional travel agents or by independent software companies. Online business travel management solutions aim to streamline and enhance the monitoring of the customer's travel purchasing processes in order to decrease the customer's travel expenses and to enhance the provision of travel services (Sigala, 2007). Adopting e-communication and e-procurement practices to avoid being left behind or being overtaken by competitors is important for travel agencies (Andreu, Aldás, Bigné, \& Mattila, 2010).

University travel purchases (the focus of our case study) have some distinctive characteristics compared to other corporate travel. First, several funding sources exist (government, research funding agencies, EU, private foundations, etc.). Common to all these sources is the limited amount of money allocated to travel. Second, travel destinations are worldwide and no standard/repeating destinations typically exist. Third, in conferences and workshops the hosting partner typically negotiates and selects the accommodation alternatives for participants. Fourth, the travellers are very cost-conscious due to their limited travel budgets, which entices them to find cheaper alternatives outside existing contracts. Typically, end-users engage in off-contract buying to find lower prices without taking account of the total cost of ownership for their organization, as purchasing process costs are not deducted from their budget. All of these factors complicate the control of travel purchases compared to many private organizations.

\subsection{Control and commitment strategies in travel policy compliance}

Ensuring compliance with purchasing policies is important when individual employees have direct access to suppliers (van der Valk \& van Iwardeen, 2011), as is the case in corporate travel. The buyer has to be able to translate and communicate the demands of internal end-users (the travellers) to partners on an on-going basis (Fredendall, Hopkins, \& Bhonsle, 2003; Wynstra et al., 2006). It is also important for travel intermediaries and suppliers providing travel-related services to understand not only travellers' preferences, but also the buyer organization's travel policy (Douglas \& Lubbe, 2006). Conflicts may arise if travellers' needs and requirements do not coincide with company goals, such as keeping expenses low (Douglas \& Lubbe, 2006). Corporate travellers may also have specific needs concerning technology, accommodation and transportation (Chu \& Choi, 2000; Mason, 2002; Andersson-Cederholm \& Gyimóthy, 2010; Han, Ham, \& Baek, 2012), and thus they may buy services outside the contract to get more 
agreeable travel conditions. Travellers may also use off-policy booking channels to get cheaper rates (Lubbe \& Douglas, 2009).

The two key strategies identified for corporate travel management are i) control-oriented strategies based on formal rules and strict management to ensure policy compliance, including sanctions against non-compliance and ii) commitment-related strategies, which aim to enhance involvement and a sense of responsibility among employees.

The control and commitment strategies were first emphasized in human resources research, and more specifically in Walton's (1985) work in which he distinguished these two ways of managing employees. The former seeks to control people through standardization, close supervision, hierarchies and other types of control. The latter relies on involving employees so that they commit to self-regulation of their behaviour (ibid.). Arthur (1994) further developed Walton's arguments into two different human resource systems. Later studies (see for example Lepak \& Snell, 1999; 2002) have revealed that firms use human resource practices that fall between these two systems. Gustafson (2013), based on human resource management and work organization research, found that travel management practices typically had elements of both control and commitment strategies, although the degree to which the strategies were applied varied between the organizations and between the stages of the travel management process. Thus, travel management may use both control and commitment-based strategies at all stages in the travel process, and both will be discussed in detail below.

\subsubsection{Control strategies}

Control is about ensuring individuals or teams act according to desired goals (Harmancioglu, 2009). Control has long been recognized as an important aspect of an organization's management of exchange relationships (Aulakh \& Gencturk, 2000). With respect to travel and tourism, control has been studied, for example, in the context of inter-organizational relationships between tour operators and accommodation companies (Medina-Munõs, MedinaMuñoz, \& García-Falcón, 2003) and in the context of controlling airline alliance partners (Pansiri, 2008). Most studies on purchasing control relate to controlling suppliers (see e.g. Aulakh \& Gencturk, 2000; van Hoek, 2000; Harmancioglu, 2009). This is also the case in triadic settings, where the focus is on controlling the service delivery of suppliers (Van der Valk \& van Iwaarden, 2011). However, internal contract users may also act non-compliantly, which requires control within the purchasing process. In the current study, control relates to the internal control of corporate travellers, happening in an exchange relationship setting within the triad.

Control can focus on processes or outcomes (Aulakh \& Gencturk, 2000). Process controls are aimed at influencing the means used to achieve desired ends, while outcome controls are aimed at setting performance standards as outcomes for activities (Bonner, 2005). Corporate buyers manage travel purchases mainly by developing an effective travel policy (Douglas \& Lubbe, 2006; 2009). A travel policy communicates the organization's philosophy and basic rules on travel, and is targeted at travellers, their supervisors and the travel staff (Rotschildt, 1998). A travel policy should encourage compliance among travellers by, for example, setting actual and reasonable guidelines, explaining the rationale behind them, identifying guidelines for making travel arrangements, establishing parameters for corporate travel-related costs, and setting the penalties for non-compliance (Mason, 2002; Douglas, 2008; Gustafson, 2012; 2013). Thus, a travel policy is a formal means of control (Gustafson, 2013), with both process and outcome control characteristics (Aulack \& Gencturk, 2000). The organization is responsible for creating a 
clear and understandable policy with no grey areas, communicating the policy, and ensuring senior management's commitment (Douglas, 2008; Douglas \& Lubbe, 2009; Gustafson, 2013). Travel policies also increasingly address safety and security issues. When they use the preferred travel suppliers and stay within the policy guidelines, travellers can easily be contacted in emergency situations, for example (Alamdari \& Mason, 2006; Douglas \& Lubbe, 2009).

Internet technology is commonly utilized to manage corporate travel and mainly represents a form of process control. Lubbe and Douglas (2009) divide the internet environment into three broad categories: (1) the 'unmanaged' internet, (2) supplier-driven self-booking systems, and (3) custom-designed self-booking systems for corporate travel management. The unmanaged internet offers the buyer no possibilities to manage travel purchases, and travellers can buy trips without any consideration to the travel policy (i.e. there are no opportunities for process control via this channel). Supplier-driven self-booking systems link buyers - mainly small and mediumsized companies with limited travel budgets - to the suppliers' websites, thus allowing them to register online and gain the benefits of discounted travel and management information. Customdesigned self-booking systems permit a technology partnership between travel agencies, suppliers and corporate buyers, and make it possible to standardize employees' reservation processes (cf. Lubbe \& Douglas, 2009).

The trend in the majority of companies is towards stricter travel policies, with business travellers being forbidden to make independent decisions regarding their business trips (Mason, 2002; Holma, 2012). Nevertheless, it is difficult to prevent purchases taking place outside the formally defined processes (Angeles \& Nath, 2007), and corporate travellers can bypass cost-effective, impersonal booking systems (Andersson-Cederholm \& Gyimóthy, 2010). In such cases the travel agency can act as an inspector, monitoring employee bookings and reporting to the client's travel manager (ibid.). Thus, business travel agencies (travel intermediaries) can play an important role in controlling corporate travel costs with the help of the powerful tools they have developed for control-based management (Gustafson, 2013).

To conclude, business travellers are internal contract users who have direct access to suppliers. Corporate travel buyers implement travel policy by communicating the general rules of business travel to travellers and other employees that take part in the travel management process. Policy compliance is mainly executed via formal control mechanisms. The policy contains guidelines for processes and outcomes and for the booking system. Internet technology is used to monitor processes in co-operation with a travel intermediary.

\subsubsection{Commitment strategies}

Overly restrictive travel policies may become increasingly difficult to implement, and the rate of compliance may fall (Douglas \& Lubbe, 2009; Mason, 2002; Holma, 2012). Business travellers differ from other employees in terms of their work, often holding high positions in the hierarchy (Gustafson, 2006; 2012; 2013). Enforcing compliance on employees who are valuable and unique to a company and who enjoy greater autonomy (Melián-González \& Verano-Tacoronte, 2006) can thus be difficult and lead to contempt for control-based strategies and, paradoxically, inefficiencies. In such cases, it is desirable that managers should find a balance between control and commitment-based strategies (Koopman, 1991). Yet, research on commitment-based strategies in travel management has been very limited so far (Gustafson, 2013).

In inter-firm relationships, informal social controls often complement formal controls (Granovetter, 1985), and desirable behaviour is encouraged by fostering mutual trust (Dyer and 
Singh, 1998). Within companies, commitment-based strategies in human resource management rely on a higher level of employee involvement in managerial decisions (Arthur, 1994) and on each employee's self-control, rather than on external control by managers. The aim is to foster a greater sense of involvement, participation and responsibility among employees (Gustafson, 2013). Studies in human resources management also emphasize the influence of organizational culture and the degree of work autonomy on control and commitment strategies. Social control is a more informal form of control (Aulakh \& Gencturk, 2000), in which organizational culture and social pressure are used to control individuals (Andersson-Cederholm \& Gyimóthy, 2010; Aulakh \& Gencturk, 2000). Gustafson (2012) highlights the importance of the example set by senior managers, who are often frequent travellers themselves, in legitimizing a travel policy (see also Douglas, 2008). For example, when such managers use economy class, this can be construed as a form of social control (Aulakh \& Gencturk, 2000).

Commitment strategies in corporate travel management have a link with literature on purchasing's internal service quality. For a long time, purchasing evaluations relied on price and other cost aspects, but including purchasing department's internal service quality as a metric is an important enrichment (Large \& König, 2009). A unit requesting products is seen as an internal customer of a purchasing unit supplying internal service (Large \& König, 2009). Thus, in corporate travel, the internal customers are the travellers, and the internal service provided by the purchasing unit includes the travel purchase process and the travel policy. Existing research shows that internal service quality, i.e. "employee satisfaction with the service received from internal service providers" (Hallowell, Schlesinger, \& Zornitsky, 1996:21), has a positive impact on employee job satisfaction and commitment to the organization (Bai, Brewer, Samons, \& Swerdlow, 2006). Stanley and Wisner (2001) find that the internal service quality provided by a purchasing unit is positively influenced by cooperative purchaser-supplier relationships. They also show that purchasing has a significant role in communicating quality expectations to suppliers, due to its boundary spanning role. Frendendall et al. (2005) also conclude that purchasing's external cooperation contributes to internal service performance. The authors emphasize that the purchasing manager should create strong external cooperation by establishing a system of communication, and ensure shared goals with suppliers (ibid.)

According to a study by Wisner and Stanley (1999), the purchasing units that provide high internal service quality are those that are more proactive, open and ready to flexibly meet internal customer needs and expectations. Rossler and Hirsz's (1995) results further suggest that close interaction with internal customers improves these customers' perceptions of the purchasing unit's responsiveness to their needs. Internal customers of the purchasing unit also rely on the actions taken by other supporting functions such as warehousing and inventory management (Stanley \& Wisner, 2001). With reference to the purchase of corporate travel services, this means that travel secretaries and invoicing and payment handling, for example, play a key supporting role in providing high internal service quality for travellers. On the other hand, excessive travel may negatively affect business traveller productivity (Beaverstock, Derudder, Faulconbridge, \& Witlox, 2009), while restrictive travel policies may also put pressure on employee productivity, retention and the willingness to travel. Welch, Welch and Worm (2007) argue that many companies have failed to recognize that business travellers, due to their international knowledge, skills and enhanced networks, are a resource that needs to be nurtured. To avoid the negative consequences of travel, it is important for employers to consider comfort, recovery during travel, travel practicalities, and reasonable compensation for lost free time (Bergbom, Vesala, Leppänen, Sainio, Mukala, \& Smolander, 2011). Corporate travel purchases must thus be 
managed in such a way that employees will find travelling pleasant and will not be burdened by the process of ordering it and reporting on it later (for e.g. reimbursement purposes).

While business travellers' service quality expectations of hotel services, for example, have been studied, and a number of quality dimensions have been listed (Akbaba, 2006), these studies focus only on the external service quality provided by suppliers (i.e. the travel providers). In general, very little research has addressed business-to-business service quality (Niranjan \& Metri, 2008; van Iwaarden \& van der Valk, 2013), while studies on corporate travel have not explicitly addressed internal service quality (see e.g. Gustafson, 2013) related to the whole process of corporate travel starting from the travel request all the way to post-travel reimbursement.

To summarise, overly restrictive travel policies may lead to a low level of compliance. Thus, it is important to find a balance between control and commitment-based strategies, and there is a need for deeper investigation of commitment-oriented strategies in corporate travel management. The desire for work autonomy and the influence of corporate culture are factors that are known to have an impact on the application of control and commitment-based strategies. Internal service quality is important in committing end-users to internally provided services.

\section{Methodology}

This paper presents a case study showing how compliance with corporate travel purchase policy can be ensured in a triadic setting. Case-based research is relevant when little is known about a phenomenon and when the existing perspective is insufficient (Ghauri, Grönhaug, \& Kristianslund, 2002). Case studies have frequently been used in travel and tourism research (Xiao \& Smith, 2006) and several authors have encouraged the use of qualitative techniques in tourism research (Komppula, 2014). Case studies are suitable when we ask how or why something is being done (Ellram, 1996; Barratt, Choi, \& Li, 2011). We will take the service triad of the buyer, the travel intermediary and the technology provider as the unit of analysis, and will investigate the way in which these actors co-operate to develop travel management processes and the resources they allocate to promote travel policy compliance. The current study is both exploratory and descriptive in nature. The case study method is useful in the early phases of research when there may be no prior hypotheses or previous work that could be useful (Sachan \& Datta, 2005).

\subsection{Unit of analysis}

Corporate travel is a multifaceted phenomenon with a variety of service offerings and a complex network of organizations involved in service development and delivery (Zhang et al., 2009; Andersson-Cederholm \& Gyimóthy, 2010; Gustafson, 2013). Business relationships are typically studied from a dyadic perspective (Dwyer, Schurr, \& Oh, 1987; Zhang, Cavusigl, \& Roth, 2003) although a group of three actors has been argued to be the smallest conceivable unit of analysis by which it is possible to study connections between relationships (Ritter, 2000; Choi \& Wu, 2009). So far, there have been few cases in which at least three stages in a supply chain have been described and analysed in empirical research (Seuring, 2008; Mena, Humphries, \& Choi, 2013). In this study we use a service triad as the unit of analysis. The concept of a service triad has been developed to describe triads in which the service is outsourced and delivered directly to end-users (van der Valk \& van Iwaarden, 2011). Thus, the buyer saves in administrative costs by 
not being involved in service delivery, but risks losing control because the service is delivered directly to the end-user (Li \& Choi, 2009).

We will focus on corporate travel and on a focal triad consisting of a buyer organization, its business travel agency (also called Travel Management Company) and its technology providing partner (the supplier), and their cooperation on two levels: the managerial level and the operational level. In general, triads can involve two types of customers: the buyer and the endusers (organizations or individuals) (Holma, 2012). Our approach in this study is different, due to the fact that the customer comprises both the buyer (the organization) and the end-users (the travellers). This is a typical situation in indirect sourcing, where end-users are involved in ordering. Thus, we add - to the earlier service triad discussion - an option in which the end-users can also exist inside the buying organization.

Our case study includes the three main actors that participate in travel management to increase travel policy compliance in the focal triad: the buyer (Aalto University in Finland, hereinafter Aalto), the Business Travel Agency or intermediary (hereinafter BTA), and the Technology Provider (hereinafter TeP). The control and commitment strategies in travel management are investigated from the buyer's perspective. Berne, Garcia-Gonzales and Mugica (2012) suggest that intermediaries should develop their customer relationships and services in order to maintain their current positions in the travel supply network. One way for intermediaries to develop eservices is by co-operating with technology providers (Buhalis \& Licata, 2002). Technology providers (suppliers) in travel supply networks include companies providing Global Distribution Systems (GDS), such as TeP in this study. The buyer was selected due to the fact that it has put considerable effort into developing its services, and because its strategy statement specifically states that research results should be utilized in service development.

\subsection{Data collection}

The three primary qualitative techniques used in the case study method are direct observation, recordings, and interviews (Ellram, 1996), all of which are included here. Firstly, we conducted in-depth interviews with the three organizations - with the head of procurement in the buyer organization, and with directors and managers from BTA and TeP - six persons in all (see Table 1). We also interviewed the manager responsible for travel management in Hansel, the central procurement unit of the Finnish Government, which puts contracts out for tender. The interviews were conducted during 2012 and 2013, each lasting 1-2 hours. There were two interviewers present at all interviews. Secondly, we used other information sources such as industry reports, other publicly available information, and documents provided by the interviewees. Thirdly, direct in-depth observation was possible, due to two of the authors being end-users of the travel services in the buyer organization.

Table 1. Basic information from the interviews.

\begin{tabular}{|l|l|l|l|}
\hline $\begin{array}{l}\text { Institution/ } \\
\text { company }\end{array}$ & Date of interview & \multicolumn{1}{|l|}{$\begin{array}{l}\text { Length of } \\
\text { interview }\end{array}$} \\
\hline Aalto & February 3, 2012 & 2 hours & Head of Procurement \\
\hline BTA & February 13,2012 & 1 hour 50 minutes & $\begin{array}{l}\text { Managing Director } \\
\text { Business Development Manager }\end{array}$ \\
\hline
\end{tabular}




\begin{tabular}{|l|l|l|l|}
\hline TeP & February 13, 2012 & 1 hour 30 minutes & $\begin{array}{l}\text { Managing Director } \\
\text { Marketing Director } \\
\text { Online Portfolio Manager }\end{array}$ \\
\hline Hansel & February 14, 2012 & 1 hour 45 minutes & $\begin{array}{l}\text { Category Manager, Travel } \\
\text { Management }\end{array}$ \\
\hline Aalto & May 30, 2012 & 2 hours & Head of Procurement \\
\hline Aalto & March 18, 2013 & 20 minutes & Head of Procurement \\
\hline
\end{tabular}

During the analysis phase, we were able to fill in gaps in the data by arranging several telephone interviews and e-mail discussions, due to our good access to the case. Gummesson (2000: 32) discusses the different dimensions of access: physical access, which is a basic condition for research, continued access, making it possible to complement data, and mental access, which refers to the researcher's ability to get on the same plane of thinking as the informant, the insight to ask the right questions and draw the right conclusions. Physical and continued access to the buyer was guaranteed by two of the authors who are employed by the buyer organization. Furthermore, one of the authors has established contacts with the actors in corporate travel through a long professional career in the travel industry, which helped to get physical and mental access to the buyer's partners.

A good interview unveils thoughts, feelings, and lessons learnt, not only to the interviewer, but also to the informant. It is a reflective process, which affects both the interviewer and the informant (Patton, 1990: 354). We managed to get the informants interested in the research and its findings. Our informants were willing to cooperate, because they saw the opportunities to reflect on present practices and find ways to cooperate more efficiently and effectively.

\subsection{Data analysis}

Decrop (1999) suggests the use of triangulation to enhance the trustworthiness of qualitative research in the travel and tourism context. We used different types of triangulation (Denzin, 1978): data triangulation (primary data from interviews, observations and secondary data involving company documents and industry reports), method triangulation (direct observation, recordings of interviews) and theoretical triangulation (utilizing ideas from purchasing, travel management, human resources management and triad literature). Furthermore, we applied two types of investigator triangulation. Several researchers interpreted the data, and the informants reviewed a draft of the paper in order to avoid any misunderstandings.

In the analysis, we discuss how activities and resources are developed in the focal triad in order to enhance policy compliance, and to prevent non-compliant purchases. We transcribed and coded all interviews. The categories in the coding that are based on the literature are the control approach and the commitment approach. But, based on our unit of analysis triad, we also coded triadic cooperation. Table 2 shows how we developed the coding categories (a method adapted from Bhakoo \& Choi, 2013). In the analysis, we present some sample comments from the interviews (Tables 3-5). In the tables, we have divided the comments by our sources of information, and have juxtaposed the comments related to Aalto's internally applied control and commitment practices with those related to the triadic cooperation. 
Table 2: Description of coding categories.

\begin{tabular}{|c|c|}
\hline Coding category & Description \\
\hline Control & $\begin{array}{l}\text { Instances where interviewees discussed: travel acceptance procedures, pre- } \\
\text { control, different units'/supervisors' control measures, non-compliance } \\
\text { statistics, technology that restricts travellers' choices, tools to control, } \\
\text { customized content of on-line bookings, specified parameters. }\end{array}$ \\
\hline Commitment & $\begin{array}{l}\text { Instances where interviewees discussed: the use of common sense, } \\
\text { freedom, responsibility, trust, convenient travel, general guidelines, } \\
\text { encouragement of own thinking, directional leadership, end-users' needs, } \\
\text { training for travellers. }\end{array}$ \\
\hline $\begin{array}{l}\text { Triadic } \\
\text { cooperation }\end{array}$ & $\begin{array}{l}\text { Instances where interviewees discussed partners' involvement in: joint } \\
\text { targets, (triadic) collaboration, joint meetings, system integration, and joint } \\
\text { coordination. } \\
\text { Instances where interviewees discussed the roles in the triad, } \\
\text { interdependence, the need for partners. }\end{array}$ \\
\hline
\end{tabular}

The analysis relies on systematic combining. The main characteristic of systematic combining is "a continuous movement between an empirical world and a model world" (Dubois and Gadde, 2002: 554). Systematic combining is closer to an inductive, rather than a deductive, approach. It has similarities with grounded theory (Glaser and Strauss, 1967), where theory is systematically created from data (Dubois and Gadde, 2002). However, while grounded theory relies on a 'loose and emerging' framework, systematic combining relies on a 'tight and emerging' framework (Dubois \& Gadde, 2014: 1279). Before going deeper into the analysis, we will next describe the focal triad and the relationships between the organizations.

\subsection{Description of the triad companies}

Aalto is the buyer that purchases its travel services from the BTA. The relationship is based on a contract. BTA is the service seller that acts as an intermediary. TeP is the supplier that provides contracted services to BTA, and, through BTA, to Aalto. TeP's role in BTA's service offering is highly important. The relationship between Aalto and TeP is indirect; i.e. Aalto has no contract with TeP (see Figure 1). Thus, in the focal triad of Aalto-BTA-TeP, TeP does not provide services directly to the customer (Aalto's management and end users, i.e. the travellers), but only via BTA, and the contract is between BTA and TeP. However, TeP is involved in service development in the focal triad. These aspects increase the complexity of the relationships in the triad and in the network to which it is connected. Both, the BTA and TeP describe the relationships in the focal triad as "three-party cooperation". 


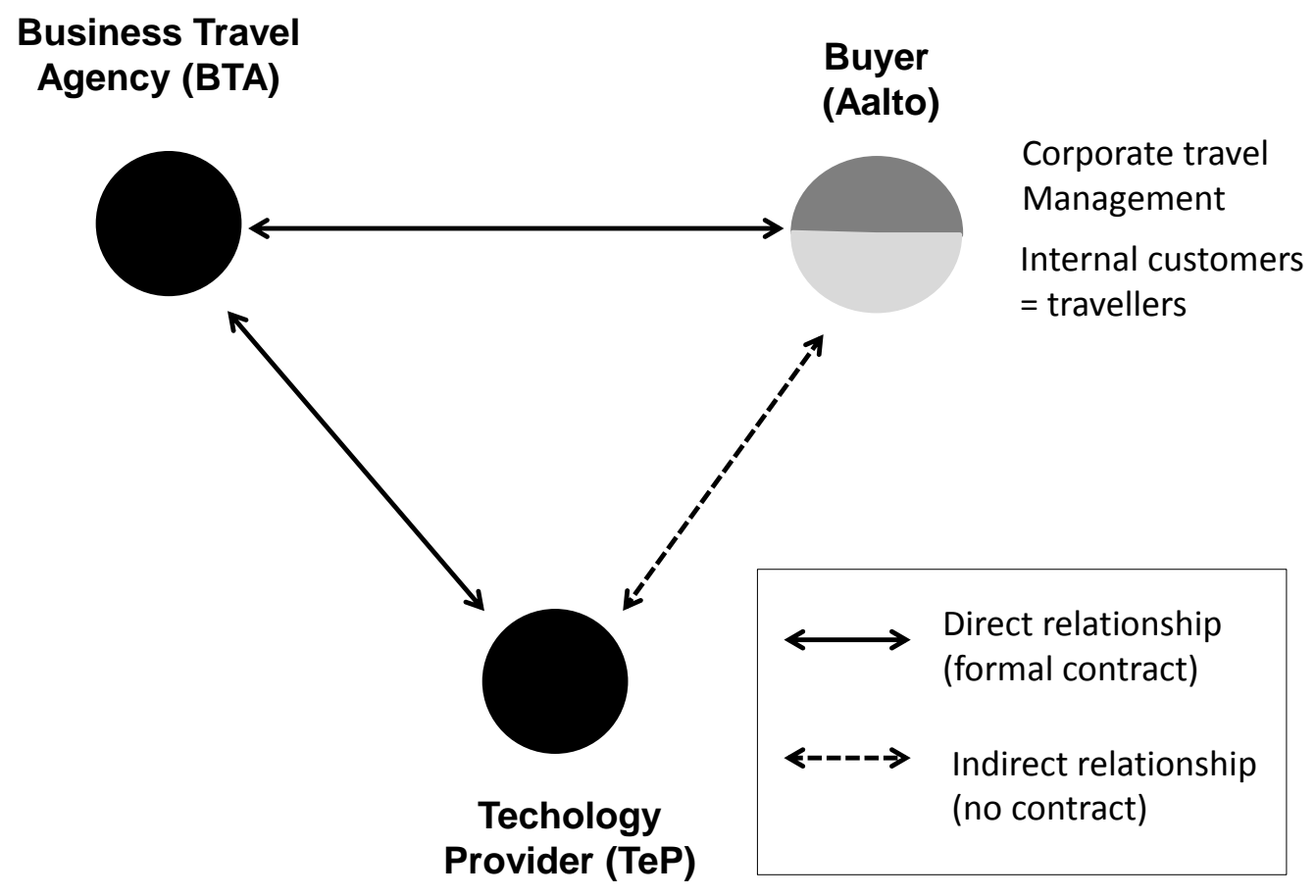

Figure 1. The focal triad and connections between the actors in the study.

Aalto University is located in Finland and has 13,000 students, and a staff of 5,300, of whom 370 are professors. In Aalto, the procurement of travel and other services follows the rules laid down in national procurement legislation and the directives of the European Union. With respect to travel and many other services, Aalto benefits from the contracts put out to tender by Hansel Ltd, which is the central procurement unit of the Finnish Government, set up to negotiate procurement contracts for the products and services required by public administration bodies, and which provides the related framework agreements. Aalto's travel costs were $€ 13.6$ million in 2012, divided between c. 2,500 travellers, who made c. 20,000 business trips. The number of flights annually is approximately 6,700 , of which the majority $(6,100)$ are international. The main reasons for travel are research and teaching. One challenge for travel management is the public procurement process and the inability to create a long-term strategic partnership with BTA in process development and integration, as public contract durations are limited by law and incumbents cannot be favoured when putting out new tenders.

BTA is a travel intermediary established over 100 years ago. BTA is a member of a world-wide organization with a network of agencies in more than 140 countries. BTA specializes in corporate travel, and the service concept is tailored to meet the requirements of different clients. Clients with large travel budgets can outsource the travel management function, or parts of it, to BTA. The product family developed by BTA facilitates information distribution, travel planning, booking, and administration. BTA also provides reports to manage travel costs, travel behaviour and supplier performance.

TeP is well-known in the travel industry for its comprehensive service offerings and technology support. TeP's customers include several types of B2B travel providers, such as airlines, hotels, car rental companies, railway companies, ferry lines, cruise lines, insurance companies, tour 
operators, travel sellers (travel agencies), and travel buyers (corporations and travellers). TeP's four service solution categories are: distribution and content, sales and e-commerce, business management, and services and consulting. TeP is present in over 200 markets worldwide. TeP provides BTA with automation solutions for service processes such as issuing tickets, invoicing and book-keeping. Partnerships between $\mathrm{TeP}$ and any business travel agency allow corporations to buy online booking solutions that are part of an integrated travel proposal.

\section{Monitoring Aalto's corporate travel purchases}

\subsection{Aalto's corporate travel and the strategies applied to ensure policy compliance}

In Aalto, travel arrangements are managed by a centralized function (Douglas \& Lubbe, 2006). The travel management function has a managerial level and an operational level. The managerial level decides on outsourcing and travel policy issues. The operational travel management level deals with travellers' daily travel arrangements and the interface between BTA and the travellers. Aalto has outsourced certain parts of its operational travel management (the flights), and has allocated the responsibility for corporate travel purchases to the head of procurement. This practice is based on the findings of Holma (2012) and Morrison et al. (1994). The head of procurement is responsible for corporate travel purchases, and this constitutes 20-30\% of his working hours. When asked how travel procurement differed from other procurement functions, the head of procurement highlighted four differences: 1) close co-operation with the business travel agency and supplier partners, 2) process integration, 3) the high number of transactions, and 4) the high level of knowledge required to manage the corporate travel function.

Aalto uses both control and commitment-based strategies to ensure travel policy compliance. The implementation of these strategies is discussed below. In Table 3 we have collected sample comments relating to both of these strategies from Aalto. Table 5 gives further comments from all parties regarding how the members of the triad contribute to both strategies (to be discussed in section 4.2). 
Table 3. Examples of Aalto's comments related to internally applied control and commitment-based strategies

\begin{tabular}{|c|c|}
\hline $\begin{array}{l}\text { Control/ } \\
\text { Commitment }\end{array}$ & Sample comments \\
\hline \multirow[t]{7}{*}{ Control } & $\begin{array}{l}\text { The travel process is very simple. It involves a general plan, a reservation, the trip, an invoice, and reporting. It's not rocket science, if one } \\
\text { understands the process. }\end{array}$ \\
\hline & $\begin{array}{l}\text { The traveller seeks acceptance from two parties. It is important to inform your superior and ask from the person responsible of budget [e.g. } \\
\text { department head] if it is ok to travel.... The traveller should check first whether there is sufficient money for the trip. Our travel policy tackles this } \\
\text { so that the person responsible of the budget ensures that there is money for the travel. The travel policy states that one should first agree with } \\
\text { one's superior, and then take the travel plan to the person responsible of budget for a decision. }\end{array}$ \\
\hline & $\begin{array}{l}\text { The employer must know where the employees are. This is positive HR policy. For example, if something happens during the trip, the traveller } \\
\text { can be helped. Insurance companies also expect some sort of control over where people travel under the travel insurance policy. }\end{array}$ \\
\hline & $\begin{array}{l}\text { BTA doesn't know which travel plans have been accepted in Aalto. This is currently under Aalto's internal control. One can travel when the plan } \\
\text { is accepted. The trip reservation may also be made after a verbal acceptance. }\end{array}$ \\
\hline & $\begin{array}{l}\text { For example, we have calculated from the expense and travel management system (M2) how many trips have been paid from the travel } \\
\text { account and how many have bypassed it. Bypassed trips have decreased from } 16 \%(2011) \text { to } 10 \%(2012) \text {. The decrease shows that we have } \\
\text { developed our services in the right direction. We don't have any pre-control for this. }\end{array}$ \\
\hline & $\begin{array}{l}\text { Who are most important parties in terms of control? They are the travel secretaries and the controllers - the travel secretaries in the earlier } \\
\text { phases of travel and the controllers in the later phases. But, of course, BTA does not sell everything it's asked to sell. }\end{array}$ \\
\hline & $\begin{array}{l}\text { If we look at our actors, they include financial services, coordination, local services such as the travel secretary in each unit, checking of the } \\
\text { plan and reservations. Coordination and policy comes from Aalto, and at the school and department level there are controllers, travel } \\
\text { secretaries, and department heads. Those who are responsible for the costs also make the decisions - so the decisions are made locally. } \\
\text { Department heads are interested in who uses the money, and what it is used for. }\end{array}$ \\
\hline \multirow[t]{2}{*}{$\begin{array}{l}\text { Control and } \\
\text { Commitment } \\
\text { combined }\end{array}$} & $\begin{array}{l}\text { If a traveller does something that is not in line with travel policy, it's no longer a travel issue, but a personnel management issue. In general, our } \\
\text { aim is to avoid excessive bureaucracy and keep rules as simple as possible.... not too much detail, but general guidelines. The departments } \\
\text { decide; we don't say no. This enables leadership. }\end{array}$ \\
\hline & $\begin{array}{l}\text { We have several small ongoing projects that will smooth the service process for our users. For example, linking directly to the expense and } \\
\text { invoices. }\end{array}$ \\
\hline \multirow[t]{6}{*}{ Commitment } & $\begin{array}{l}\text { Aalto's travel policy has a bit of flexibility regarding the use of business class. Common sense can be used when there is a situation where it is } \\
\text { really needed. Categorical denial is not sensible. }\end{array}$ \\
\hline & We want travellers to get the lowest prices [from BTA]. Our trips are foreseeable and there is typically no or little need for flexible airline tickets. \\
\hline & We encourage own thinking and actions that make sense. This approach allows case-based flexibility. If rules are too strict, they erode morale. \\
\hline & $\begin{array}{l}\text { We have a directional leadership culture in all our operations (financing, HR, etc.). We give people freedom and responsibility, and trust them to } \\
\text { act rationally and make sensible decisions.... I believe this leads to much better results than strict control. }\end{array}$ \\
\hline & t about how all development should aim at minimizing the inconvenience of the travel experience.... \\
\hline & has been on our $r$ \\
\hline
\end{tabular}




\section{Control-oriented strategies}

Aalto University's documented travel policy, which includes financial policies and guidelines for corporate travel, serves as an example of a control-oriented management strategy (Gustafson, 2013) and formal control measures (Aulakh \& Gencturk, 2000). The travel policy and the rules and guidelines for travel arrangements are available for all personnel to read on Aalto's intranet. Their objective is to guarantee that travellers get adequate support before, during and after their trips, and also to ensure that the travel is economical, appropriate and safe, and takes account of environmental issues. Douglas (2008) discovered that the use of a combination of pre-trip approvals and post-trip analyses by management is often neglected. However, Aalto approaches travel management by using a process-based view in which services and travel processes are integrated, and in which several units within Aalto are involved in controlling and supporting the travel process (see table 3). Before each trip, policy compliance is supported by a travel plan that the travellers enter in an e-based travel and expense management system. The travel plan is expected to include a realistic cost-estimate, and, if it is prepared well in advance, enables the use of inexpensive, early booking prices. The travel plan must first be approved by the traveller's superior and then be accepted by the person responsible for the budget, who is typically the head of department. Decision-making is thus decentralized, giving more responsibility to the units and supporting local control. The travel plan offers the travel secretary and head of department an opportunity to check that the planned business trip is in compliance with the travel policy; i.e. that its purpose is rational and the budget is feasible. The department head's approval follows a predefined process in which sustainability issues are also considered. The department head further evaluates whether the trip could be replaced by a video meeting, for example. This is in line with Aguilera (2008) who notes that physical travel is not always needed, since mediated communication channels (telephone, email, video-conferences, etc.) can be a feasible alternative (see also Arnfalk \& Kogg, 2003). After the trip the traveller enters a report in the e-based expense and travel management system and receives reimbursements.

Regarding post-trip control, there are several units within Aalto applying process and outcome control. The financial services unit provides help in post-transaction monitoring and reporting, and by advising on corporate travel-related issues at the university level. Controllers and travel secretaries monitor travel policy compliance in their home units. Currently, the most important links in monitoring are Aalto's own travel secretaries. They find deviations, if any, when prechecking the travel plans and checking the travel invoices. If any problems occur, it is the controllers' responsibility to act. The Service Center takes care of the payment process, and thus is responsible for payments of travel claims and advice. Meanwhile, the schools offer local support and advice to end-users.

There are some limitations on pre-control or real time control, and policy non-compliance has been a problem at Aalto. However, the percentages of bookings that have bypassed BTA have decreased, and currently the travel policy is rather well implemented. Because Aalto has no precontrol in the case of bypassed bookings, there may be a lack of information regarding the location of travellers in emergency situations. This is no problem when the booking occurs via BTA, because a register of all bookings exists and the travellers can be tracked if there is a catastrophe and a need for evacuation.

\section{Commitment-based strategies}

Aalto's head of procurement emphasizes the importance of having sensible guidelines for travel. The sample comments in Table 3 regarding Commitment show that there is room for flexibility 
and common sense. Furthermore, to ensure policy compliance, the head of procurement emphasizes that the travel services offered by external service providers must be high-quality and competitive internally (within Aalto), and that the purchase-to-pay process must be fluent and efficient. In table 3, the comments on Commitment (and those combined with Control) emphasize system design-to-user convenience and user preferences (i.e. low prices). Thus, Aalto has chosen a proactive approach to prevent non-compliance. This is consistent with the findings of Wisner \& Stanley (1999), who conclude that purchasing departments providing high levels of internal service quality could be characterized as more proactive. In Aalto, travellers' needs are taken as the starting point, and travel services and the purchase-to-pay process are continuously improved in order to make them attractive to travellers. Wynstra et al. (2006) also emphasize the buyer's ability to constantly translate and communicate the internal end-users' demands to the suppliers. The head of procurement points out that a business traveller behaves like a consumer, and that he/she cannot be forced to follow the policy. Therefore, policy compliance and a commitment to use the services can only be supported if the services are of high quality.

Some companies may regard policy compliance as a performance dimension, and may create rewards and penalties based on compliance (Douglas, 2008). In Aalto, no sanctions have been used in cases of non-compliance, and no situations have arisen in which the traveller did not get reimbursement for tickets purchased outside the policy. This is in line with Gustafson's (2013) findings that strongly control-oriented measures are exceptions. Aalto's aim is to solve the noncompliance problem in two ways. Firstly, in line with human resources management research (see e.g. Walton, 1985; Arthur, 1984) commitment is supported via employee self-control, and thus travel decision-making is decentralized to the units (read "department heads") which are in charge of the units' budgets. In addition, de-centralized decision-makers operate close to the travellers, which supports effective personnel management. In other words, superiors and department heads can react fast in cases of non-compliant behaviour and, through discussion, can promote traveller self-control and commitment (social control). Secondly, greater commitment can be fostered by developing services and the purchase-to-pay process, rather than by increasing control. According to Gustafson (2013), the balance between control and commitment-based strategies reflects the organizational positions of respective travel managers. In Aalto, the head of procurement has strong support from the university's top management and a strong mandate to develop services proactively. Current developments in policy compliance support Aalto's commitment-oriented strategies.

\subsection{Cooperation in the focal triad}

The development of control and commitment-based strategies in travel policy compliance relies on cooperation between Aalto, BTA and TeP. All three parties agree that the coordination of travel purchases would not be possible without the technology platform provided by TeP, the ability to apply this technology in meeting Aalto's needs provided by BTA, and the first-hand familiarity with Aalto's and Aalto's travellers' needs provided by Aalto.

The triadic cooperation benefits all three parties, as the comments in Table 4 show. For BTA, improved control to prevent off-contract purchases ensures that BTA gets its expected share of Aalto's travel purchases, as long as the terms of the contract are fulfilled (Karjalainen et al. 2009). Furthermore, Aalto is a very important partner for BTA, not only as a buyer, but also because Aalto was one of the founders and an active member in a Service Lab that BTA launched in 2011. The Lab aims to develop, optimize and test new innovative service concepts.

Co-development, such as the Service Lab concept, typically requires long-term cooperation, 
mutual trust between the partners, and knowledge of each other's resources and capabilities. In public procurement, the required competitive bidding limits this kind of in-depth cooperation. TeP's strategy is to serve corporate buyers' through BTAs, and thus there is no contract between Aalto and TeP. However, TeP engages in a consulting role at meetings where service development is discussed. TeP regards this type of cooperation as fruitful.

For Aalto, triadic cooperation has led to efficient travel management practices. The explicit benefits of triadic cooperation relate to technology development that allows the automated control-oriented monitoring of travel purchases (Holma, 2012). More efficient use of technology, in turn, increases the quality of the services by which commitment-based strategies can be applied. Thus, cooperation in the focal triad fosters both control and commitment-oriented strategies in travel management. The roles and viewpoints of each triad member regarding both strategies will be discussed in more detail below, and are exemplified by the interview comments in Table 5. 
Table 4. Comments from Aalto, BTA and TeP regarding the triadic relationship

\begin{tabular}{|c|c|c|}
\hline \multicolumn{3}{|c|}{ Triadic cooperation } \\
\hline Aalto & BTA & TeP \\
\hline $\begin{array}{l}\text { When I started with this, I found it interesting to work in this } \\
\text { business, as we collaborate in a positive and open } \\
\text { atmosphere. Sellers and buyers, with BTAs in between, } \\
\text { communicate and share ideas and, in this way, develop } \\
\text { things. Competitors also collaborate on some level. }\end{array}$ & $\begin{array}{l}\text { In the triad TeP is the enabler and Aalto is the customer } \\
\text { for both of us. Our interests are not in conflict. We in } \\
\text { BTA conceptualize the service and TeP makes it } \\
\text { possible. }\end{array}$ & $\begin{array}{l}\text { Our strategy states that we have business } \\
\text { relationships only with travel agencies. However, } \\
\text { in practice we also have direct dialogue with } \\
\text { companies. }\end{array}$ \\
\hline $\begin{array}{l}\text { There is network consisting of BTA, a credit card company, } \\
\text { the airlines and TeP. The whole network helps in building } \\
\text { the infrastructure and services so that this process works. }\end{array}$ & $\begin{array}{l}\text { We are in a triad where we all need each other. What if } \\
\text { we did not have this coordinating global distribution } \\
\text { system provided by TeP? Everyone could buy from } \\
\text { everywhere. It would all go wild without Tep. Tep is a } \\
\text { key partner in business travel. One could say that we } \\
\text { can all buy from the internet, but then one forgets the } \\
\text { holistic travel process. We all need each other. }\end{array}$ & $\begin{array}{l}\text { Our channel, with BTA in between, is pretty } \\
\text { successful.... We regularly meet our customers } \\
\text { and discuss the needs of their [the travel } \\
\text { agencies' ] customers; i.e. where to pursue } \\
\text { what. So we take part in the consulting work. }\end{array}$ \\
\hline $\begin{array}{l}\text { We do not have direct contract with TeP, but we } \\
\text { collaborate and meet each other in profile integration } \\
\text { projects, for example. TeP's role is to back up BTA. }\end{array}$ & & $\begin{array}{l}\text { In triadic collaboration the aim is to discuss } \\
\text { needs. }\end{array}$ \\
\hline $\begin{array}{l}\text { The role of BTA has changed. Nowadays it is a process } \\
\text { partner and one of the IT integrators. Its role is to be an } \\
\text { integrator. This role cannot be replaced - there needs to be } \\
\text { a party that designs and implements. This is not our role. } \\
\text { Credit card companies process transactions. This is a } \\
\text { fantastic puzzle, with different types of components. The } \\
\text { big picture is built from these components, and is carried } \\
\text { out by a consulting type of process. }\end{array}$ & & \\
\hline
\end{tabular}


Table 5. Comments on control and commitment from Aalto, BTA and TeP regarding the triadic relationship

\begin{tabular}{|c|c|c|}
\hline \multicolumn{3}{|c|}{ Control } \\
\hline Aalto & BTA & TeP \\
\hline $\begin{array}{l}\text { IT systems are needed, as processes are } \\
\text { implemented with IT systems. Then we need } \\
\text { instructions that set boundary conditions. And finally } \\
\text { we need partners and networks. }\end{array}$ & $\begin{array}{l}\text { There are two systems in the online system: one for } \\
\text { BTA's service personnel, and the other for their } \\
\text { customers. Behind this are about } 3000 \text { parameters from } \\
\text { which customer-based content can be executed. There } \\
\text { are many things that are customized... }\end{array}$ & $\begin{array}{l}\text { We contribute a tool to check compliance with travel } \\
\text { policy. There is no need to use this tool, if there is no } \\
\text { travel policy. }\end{array}$ \\
\hline $\begin{array}{l}\text { As a result of negotiations between BTA and us, BTA } \\
\text { service personnel will prioritize cheaper alternatives in } \\
\text { their offering. And as our travel policy aims at travel } \\
\text { cost efficiency, changes have been made in the } \\
\text { online system. Earlier, BTA offered contract prices } \\
\text { first, which was a step in the wrong direction. }\end{array}$ & $\begin{array}{l}\text { BTA specifies the parameters to be used in our service } \\
\text { and by which we can support travel policy. The aim is to } \\
\text { help customers, and also to train them. }\end{array}$ & $\begin{array}{l}\text { It's important to have a travel policy. The travel policy } \\
\text { makes it possible to provide travellers with the data } \\
\text { that one wants to provide them with. It kind of controls } \\
\text { the information. }\end{array}$ \\
\hline $\begin{array}{l}\text { BTA provides us with process benefits, and we know } \\
\text { where our travellers are. If you purchase via the } \\
\text { internet, you do not have a real-time view... }\end{array}$ & $\begin{array}{l}\text { Our aim in reporting purchases is to always give an } \\
\text { accurate picture and thus create added value for our } \\
\text { customers. Another big added value is the linking of } \\
\text { travel policy to the service system. Our aim is not to sell } \\
\text { tickets, but to facilitate the whole travel process. It's a } \\
\text { holistic role. }\end{array}$ & $\begin{array}{l}\text { We provide a channel within which our customers can } \\
\text { do their work. We're not separate. Our strategic policy } \\
\text { is not to sell services directly to companies, but to } \\
\text { BTAs. We have a store of products and service } \\
\text { packages for our customers. This is actually a pretty } \\
\text { modular system. The products place themselves into } \\
\text { different parts of the process....Corporate customers } \\
\text { increasingly want to concentrate purchases, and thus } \\
\text { there is pressure on us to develop our offering. We } \\
\text { have added hotels, car rentals, etc. to our system.... } \\
\text { Our online system is the channel for BTA's total } \\
\text { offering, together with the phone and email channels. }\end{array}$ \\
\hline $\begin{array}{l}\text { It's good for travellers to get all services via one online } \\
\text { system (GDS). We can also specify what we want to } \\
\text { be visible in the portal. }\end{array}$ & $\begin{array}{l}\text { Developing the online service has been a large project } \\
\text { in Aalto. Reservations are very centralised, and a small } \\
\text { number of travellers make reservations by themselves. } \\
\text { Travel secretaries also use the online system. Our aim } \\
\text { is to increase the usage rate of online reservations. } \\
\text { This requires technology, and further development is } \\
\text { under way. With this we'll be able to specify that certain } \\
\text { reservations can only be ordered online, for example. }\end{array}$ & $\begin{array}{l}\text { It all starts from the need for logic in the travel policy. } \\
\text { Companies typically make contracts by themselves or } \\
\text { via intermediaries, and in practice these contracts } \\
\text { typically include volumes and prices. This information } \\
\text { needs to be transferred to the system. The challenge } \\
\text { in configuration is how to execute it smartly. For } \\
\text { example, are the options available in the right way for } \\
\text { travellers? }\end{array}$ \\
\hline & & $\begin{array}{l}\text { Safety is one reason why customers use our } \\
\text { technologies. }\end{array}$ \\
\hline
\end{tabular}




\section{Commitment}

\begin{tabular}{|c|c|c|}
\hline Aalto & BTA & TeP \\
\hline $\begin{array}{l}\text { It shows that this is very much a technical and integrated process } \\
\text { where there is still much to develop. The travel process doesn't } \\
\text { work without a partner network [lists partners]. All are integrated } \\
\text { closely with each other. The key concept is "modular approach". }\end{array}$ & $\begin{array}{l}\text { Our aim is to optimize our offering, and also to } \\
\text { develop automated services. All partners are } \\
\text { part of this process, and IT makes this possible. }\end{array}$ & $\begin{array}{l}\text { The online service is in the middle. TeP provides } \\
\text { solutions for its customers via BTA. It's our } \\
\text { channel of choice. }\end{array}$ \\
\hline $\begin{array}{l}\text { So in practice we meet our partners regularly.... During the last } \\
\text { two years that I've worked on this task, I've realized that, if we } \\
\text { really want to make progress and get results, it's important to } \\
\text { progress in small steps, so that all partners around the table will } \\
\text { understand the aims in practice, and changes can be made in a } \\
\text { short time frame, in two to four weeks... It doesn't work if you run } \\
\text { a project where the planning takes four months and the execution } \\
\text { two years. It just doesn't work. The development needs to be done } \\
\text { based on user needs, and in small agile steps... }\end{array}$ & $\begin{array}{l}\text { Traveller training is a big issue. The future } \\
\text { challenge will not be to train travel secretaries } \\
\text { (50 persons), but to train the travellers ( } 5000 \\
\text { persons) in terms of their awareness and } \\
\text { understanding. Travellers look at their trips from } \\
\text { the standpoint of consumers, while on the other } \\
\text { hand they present a business traveller face to } \\
\text { the company. The challenge is how to tackle } \\
\text { communication in this triad. }\end{array}$ & $\begin{array}{l}\text { Travel agencies are of strategic importance to } \\
\text { us, from two perspectives. Their traditional role } \\
\text { is to be our customers, benefiting from our } \\
\text { technology when they build their services and } \\
\text { offerings. Their other role is a reseller role, in } \\
\text { which they are part of our core business, } \\
\text { contributing an important part of our turnover. } \\
\text { We are talking now about the self-reservation } \\
\text { systems used by their and our customer } \\
\text { companies. }\end{array}$ \\
\hline This is joint business process, in which we're all in the same boat. & $\begin{array}{l}\text { Various travel situations have increased the } \\
\text { interest in mobile text message services. This is } \\
\text { a value proposition which BTA could offer and } \\
\text { for which it should get compensation. }\end{array}$ & \\
\hline \multicolumn{3}{|l|}{$\begin{array}{l}\text { We have collaborated a lot with BTA to make the lowest, most } \\
\text { competitive fares available to our travellers. }\end{array}$} \\
\hline $\begin{array}{l}\text { We had an interesting case last autumn. When we developed a } \\
\text { service team together with BTA and marketed that service widely } \\
\text { to our travellers, the number of users increased fast. As a result, } \\
\text { the service quality dropped and we had a problem. We found that } \\
\text { there was a need to increase staff by } 0.7 \text { persons. There were } \\
\text { discussions with BTA and new arrangements were made. This } \\
\text { was a good example of how, when we have a process view of } \\
\text { travel, it is possible to see where the problem is, what the reasons } \\
\text { are, what the result is, and then to be able to fix it. I believe that } \\
\text { when we develop our own operations in this way and with our } \\
\text { partners, the processes will be much better and more streamlined. }\end{array}$ & & \\
\hline
\end{tabular}




\section{Triad members' roles in developing control measures}

Aalto needs IT systems in order to implement travel policy and manage travel processes. TeP is the provider of these systems. Backed by TeP, BTA provides Aalto with automated solutions for different phases of the travel management process, and these solutions help save travel costs, simplify the travel process (by eliminating manual activities) and monitor the travellers. The travel policy is central to the triad's development work, and it is interesting to note from Table 4 that it is TeP, in particular, that emphasizes the importance of travel policy in guiding its role in the triad, and in serving the buyer correctly. The travel policy includes, for example, the contracts that Aalto has negotiated with suppliers, and this information is transferred to the travel management solution via BTA, as the integrator.

To support travel compliance, an on-line reservation system has been designed to include parameters that are consistent with Aalto's travel policy. The on-line reservation system allows travel secretaries and travellers to make their own bookings of non-complex travel online (Gustafson, 2013). The reservation system has been provided by TeP and configured by BTA to match Aalto's travel policy (Lubbe \& Douglas, 2009).

BTA is responsible for travel bookings and the on-line reservation system. After a travel plan has been approved, the individual travel bookings are always made via BTA's service team or via an on-line reservation system. The head of procurement entrusts BTA with the monitoring of travel bookings (Andersson-Cederholm \& Gyimóthy, 2010), either by training the booking personnel, or by relying on the on-line reservation system with which the travel policy is integrated. However, co-development of the services to enhance commitment is seen as more important than control. An example is the service team in BTA that is dedicated only to Aalto. According to the head of procurement, with whom BTA's service team works closely, changes have been made in response to users' proposals. For example, BTA's service team has been advised to always offer the most inexpensive means of travel, in order for users to be able to travel as cost efficiently as possible. Due to the university funding policy, low prices are important for Aalto's travellers, whose trips are foreseeable and who do not typically need flexible airline tickets. This example illustrates the application of both control-based and commitment-based strategies.

\section{Triad members' roles in committing travellers}

BTA's extensive campaign to train travel secretaries and travellers to use the on-line reservation system demonstrates one way to increase commitment. In 2012, on-line reservations accounted for about $40 \%$ of all reservations in international travel, and the aim is to increase this percentage in the future. It is further expected that increased technology adoption will enhance policy compliance, in line with the findings of Karjalainen and van Raaij (2011) that compliance will be higher when deviating from pre-negotiated contracts is made difficult. A platform for selfservice reservations is a good way to enhance travel policy compliance (Douglas, 2008; Lubbe \& Douglas, 2009) when it is done properly.

Monitoring travel policy with the aid of the focal triad of Aalto, BTA and TeP has benefits from the corporate point of view - even though, from the travellers' point of view, buying directly from the suppliers would in some cases be easier (Buhalis \& Licata, 2002). However, the increasing availability of electronic booking will support the corporate processes better in the future. In addition, the aim of cooperation in the focal triad is to bring added value to the travel booking process, e.g. through lower prices, passenger tracking possibilities and better service quality. In addition to managing travel costs, the use of BTA for travel bookings is important for 
traveller safety. BTA can track travellers and help them in emergencies. The examples listed by BTA included helping out travellers during a volcanic ash cloud, or in more common situations such as airline or airport strikes.

It is clear from Table 5 that the ways to increase commitment are mostly manifested through joint development of both the process and the offerings by triadic cooperation. The interviewees emphasise the importance of service quality in promoting user compliance. In Figure 2 we summarise the main issues related to triadic cooperation and their role in developing Aalto's corporate travel management and advancing traveller compliance.

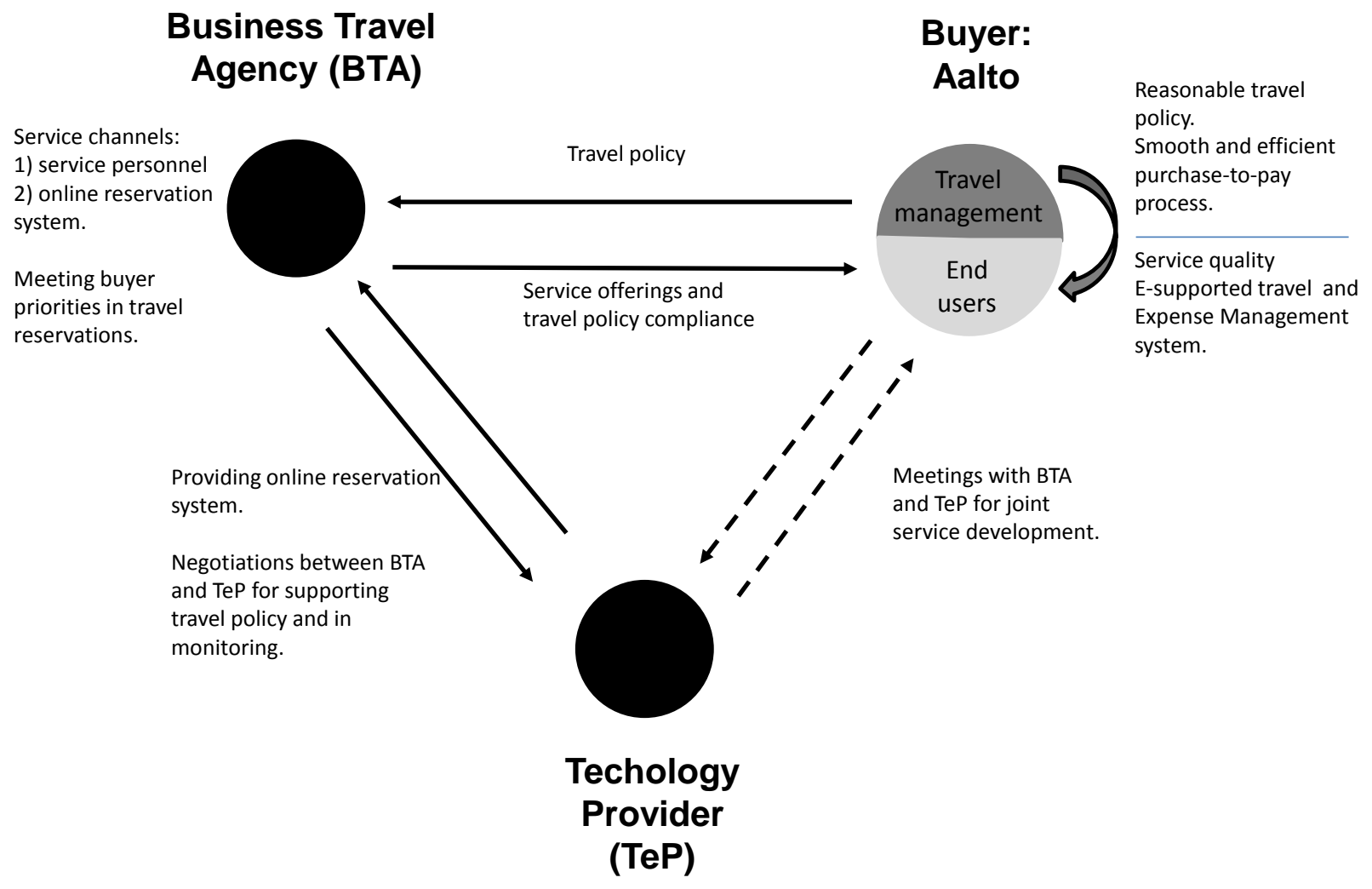

Figure 2 Triadic cooperation in developing Aalto’s corporate travel management.

\section{Discussion}

Our findings on the approaches employed to enhance travel policy compliance in corporate travel purchases, and the roles of the triad members in it, provide interesting comparisons and contrasts with the previous literature. The study demonstrates that travel policy compliance is monitored in several phases of the travel management process, and in several units, at both the organizational and unit levels. Different functional units inside the buying organization take part in delivering travel-related information and establishing monitoring practices. The key issue is 
visibility: sharing and distributing proper information between the managerial and operational levels (Holma, 2012). Development of the travel management process in cooperation with the triad members is essential for successful travel purchasing.

In the corporate travel management literature, a division has been made between control and commitment strategies (Gustafson, 2013), with the former relating to process and outcome control, and the latter representing a form of social control (Aulakh \& Gencturk, 2000). Elements of both strategies were found in our case study. The results revealed that, much more important than control per se, was the ability to enhance travellers' commitment by providing them with technology integration and good internal service quality (Frost \& Kumar, 2001) as a result of joint development in the triad. High-quality services can support travellers' sense of responsibility (Gustafson, 2013).

In line with recent research on travel booking and monitoring (Douglas \& Lubbe, 2006; Sigala, 2007; Bigné et al., 2008; Lubbe \& Douglas, 2009; Gustafson, 2013), our study confirms that technology is an efficient way to monitor travel purchases. At the beginning of the 2000s, travel managers regarded online bookings as a threat because of travellers' direct access to the airlines. They were seen as hindering minimization of travel spending and as an obstacle in monitoring travel costs (Mason, 2002). However, factors such as technology development and the forging of close partnerships between buyers, travel intermediaries and suppliers have facilitated the efficient control of travel policy compliance. In our case study, the buyer's internal systems and those provided by the triad partners allow for both outcome and process monitoring. Outcome monitoring, which verifies whether purchases have been compliant, can only be done after transactions. Process monitoring is possible in the earlier phases, and is realized at the operational unit level when end-users make their travel plans (travel secretaries and superiors) and when BTA's customer service representatives take telephone bookings. Our findings are in line with Andersson-Cederholm and Gyimóthy (2010) who show that the business travel agency and the corporate buyer's travel manager share "policing" duties with respect to travellers. The technology provider is also indirectly involved by improving the technologies used, but most of the control is conducted by the two triad members who have direct contract.

For monitoring to take place, the case study's buying organization also uses a custom-designed self-booking system, which was developed by a technology partnership in the triad (cf. Lubbe \& Douglas, 2009). Specifically, there is evidence of system selling (Ritter, 2000) in which suppliers in the triad collaborate via joint meetings to provide services tailored to meet buyer needs. The business travel agency plays the role of an intermediary in relaying the buyer's wishes to the technology provider, thus creating value as a coordinator and as a resource (Myllärniemi, Vuori, Helander, Ilvonen, Okkonen, \& Virtanen, 2013; Nätti, Pekkarinen, Hartikka, \& Holappa, 2014). A similar type of cooperation is reported in the study by Niranjan and Metri (2008) in the context of offshore third-party service providers, and by Holma (2010) in buyer-business travel agencyairline/hotel triads. Travel policies and guidelines have a prominent role in the case. They were used to specify both process and outcome targets for the end-users. Interestingly, it is the triad partners rather than the buyer organization that emphasise their importance in the process. Our findings are in line with those of Lindberg and Nordin (2008), who discovered that procurement processes are much more formal today, with guidelines and rules applied to govern service procurement activities. Gustafson (2013) found that travel managers applied both control and commitment-based strategies at different phases of the travel management process. This finding is also confirmed in our case. The travel policy is the primary instrument of formal control in Aalto, and is regulated by the Finnish Government's travel policy and EU regulations. However, 
the policy also aims to enhance employee commitment by setting reasonable and easily understandable guidelines. The case company's travel policy is designed to be easily applicable and reasonable, which motivates travellers to abide by it. This also supports Kulp, Randall, Brandyberry and Potts (2006), who demonstrate how compliance in a company improved after purchasing took an active role in posting contract information on the company intranet.

The findings that are potentially the most interesting relate to the emphasis on providing superior travel service, as mentioned by the respondents in all of the triad organizations. Excellent, easyto-use systems and process approaches, continuous development, forward-looking attitudes, and a mindset that users "must want to use the systems" were all cited as key tools to increase compliance. This emphasis on service quality is a new addition to the factors that facilitate commitment-based strategies, and relates to other studies emphasizing the importance of corporate purchasing and its internal service quality (Stanley \& Wisner, 2001; Wisner \& Stanley, 1999). Stanley and Wisner (2001) have pointed out that the role of the buyer in managing quality from external suppliers to internal customers has received little attention in the literature, even though purchasing's unique boundary-spanning role provides many opportunities for this. We have focused on that boundary-spanning role in this study, and have investigated how the buyer organization, in collaboration with the two suppliers in the triadic supply chain, has enhanced the experience for internal customers of the purchasing function, i.e. the travellers. In our study the travellers are seen as internal customers to be served, and the triad members act together to improve the process to please them through high-quality services. These findings contrast with those of Andersson-Cederholm and Gyimóthy (2010) who indicate that travel managers see travellers as non-categorisable anomalies, who "stand in the way for a clearly rationalized travel management process" (Andersson-Cederholm \& Gyimóthy, 2010, p. 276).

We set out to study the travel policy compliance of corporate travellers, but it seems that the answers to this issue are more closely related to the findings of studies on customer satisfaction and service quality in tourism, rather than of studies on control and management. According to Kim, Kim and Han (2007), the best way for online travel agencies to increase bookings is to make it easy for customers to find what they are looking for, and thus the agencies must constantly learn from their customers. This is supported by Llach, Marimon, del Mar AlonsoAlmeida, and Bernardo (2013) who find that a friendly and efficient website encourages loyalty in online purchases. Likewise, Buhalis and Law (2008:611) state that "The key to success lies in the quick identification of consumer needs and in reaching potential clients with comprehensive, personalized and up-to-date products and services that satisfy those needs". However, where quality fails to meet expectations, individuals may look for other options or for ways to circumvent official procurement processes (Croom \& Johnston, 2003), as was confirmed in our case, too, where it was shown that the best way to ensure compliance was by developing booking systems in triadic cooperation and by creating a motivational travel policy. Prior research on purchasing's internal service performance also highlights visionary leadership, which increases purchasing's internal and external cooperation, which in turn improves internal service performance (Fredendall et al., 2005). A specific factor that emerged in our case study was that the buyer (Aalto) had instructed the business travel agency to always offer the lowest prices to Aalto employees who booked via phone, as this was the key criterion for university travellers. This is also in line with consumer travel studies: Kim et al. (2007) find that, of the nine attributes for selecting online travel agencies, "finding low fares" was the most significant. 
The findings also offer several practical tips for corporate travel managers. It is argued that companies developing commitment-based strategies will perform better than companies focusing on control (Gustafson, 2013). In line with the findings of Brandon-Jones and Carey (2011), who suggest that it is difficult to force individuals to comply with systems and contracts they are dissatisfied with, even if it is mandatory, we also argue that organizations in these triadic travel service settings should focus on service (quality) development to ensure compliance. Several approaches are available, such as developing an organization's internal service quality (Marshall, Baker, \& Finn, 1998), increasing user training (Arthur, 1994; Douglas, 2008), customizing the travel booking system to suit end-user needs, and emphasizing end-user decision-making criteria when training service personnel. These harmonize with the fundamental directional change in the travel sector called for by Millan and Esteban (2004). They argue that professionals in this sector do not see service quality as a process of continuous improvement, but simply as "guiding the client" - an attitude that needs to be changed. Nevertheless, communicating the travel policy and disseminating guidelines via multiple channels is also needed in order to establish the process and set outcome targets for end-users. Travel service providers in these triadic settings - whose transaction volumes depend on end-user compliance - should take note of this, and aim to listen to customer needs in developing their offerings. This is in line with the findings of Roy (2003): Approved suppliers should not assume that winning a contract will, in itself, result in business flowing in. They must reach out proactively to the contract users.

\section{Conclusions, contributions and further research}

In this study we have analysed travel policy compliance and how three-party cooperation can support such compliance and improve corporate travel management overall. We have focused on the buyer's perspective in a service triad comprising the buyer, the travel intermediary (business travel agency) and the technology provider. The supply side of the tourism industry has received relatively little attention so far, and insufficient attention has been paid to the study of the different suppliers involved in providing travel products and services (Zhang et al. 2009). Yet the industry is increasingly networked, with multiple suppliers involved in service delivery, both for tourism and corporate travel. Our focus on triadic collaboration in developing corporate travel services thus serves to bring the fields of travel/tourism research and supply chain management closer together, as has been called for recently (Bigné \& al., 2008; Zhang et al., 2009; Andreu, \& al., 2010).

The case study offers an example of how complex travel service processes are monitored and managed in three-party cooperation. The travel policy and associated guidelines are used to set outcome and process targets beforehand, and these are actively communicated to end-users. The triad's intermediary and supplier are also instructed to offer travel bookings in line with both user preferences and the travel policy/guidelines. End-users' ability to directly access alternative suppliers via the internet, and to access the cheapest rates, limits the buyer's possibilities to monitor the purchasing process. Outcome monitoring takes place through systems developed by the triad. The main method used to ensure compliance, however, is the proactive and cooperative development of services and systems by the triad in such a way that end-users will want to commit to the travel policy and to act in compliance with it. In the case study, the buyer works actively against non-compliance by developing and providing competitive services in line with a commitment-based strategy, and by not imposing unrealistic and impractical rules on the travellers. Therefore, we argue that organizations in such triadic travel service settings should, in 
the future, focus on committing travellers to the travel policy and on providing them with added value, rather than using force or imposing sanctions for noncompliance. Corporate culture also plays an important role in travel policy control (Gustafson, 2013). In the context of our case study (a university environment in which employees have a high degree of autonomy) the above conclusions were emphasised.

The contributions of this study relate to several streams of literature. First, the study adds to our understanding of how travel purchasing and supply processes can be developed in three-party cooperation, focusing on policy compliance and monitoring. We contribute to the current business travel and travel management literature by providing an in-depth case study of corporate travel management in a triadic setting. Second, the study contributes to service supply chain research through the emerging service triad concept with an empirical case study. Our study also responds to the call for studying travel policy compliance further, in areas where quality control and assurance is shared between several organizations (Andersson-Cederholm \& Gyimóthy, 2010). Interestingly, our findings show that "policing" does not appear to be the most effective path - especially in complex organizations with limited visibility and direct user access to suppliers. On the contrary, providing superior service is the key. Another important perspective on policy compliance relates to human resource management and its connection to internal service quality. Our study makes an important contribution to earlier human resource management studies on control and commitment, by emphasising the key role of internal service quality in corporate travel management. Furthermore, we show that we may have to reach outside the organization, to external partners, in order to ensure employee commitment to internal processes. Our case study results show that a rise in internal service quality requires two approaches: improving the service quality between BTA and the travellers, and the level of quality of the internal travel management process (the purchase-to-pay process). Travellers are an important resource in companies (Welch et al., 2007) and it is important to treat them as customers, as our results point out. For practitioners, the paper offers suggestions on effective and efficient travel purchasing management.

A potential limitation of the study is the university context for travel purchases, as university travellers are extremely cost-conscious due to limited travel funding. In addition, the relevance of corporate culture in influencing travel policy compliance, as pointed out by Gustafson (2013), is particularly clear in a university context. Therefore the motivations and forms of noncompliance taking place may differ from other corporate travel contexts (e.g. more search for cheaper options rather than late bookings of business class seats). Further studies in private sector contexts are needed to investigate our results' applicability in such settings. The public sector procurement context also limits the generalizability of our results. Public procurement of services is based on the provisions of national procurement legislation and the directives of the European Union. The directives limit the possibility for long-term cooperation with service suppliers due to maximum contract durations before retendering and a ban on favouring incumbent suppliers. On the other hand, the fact that service development was still found to be a key issue in the proactive control of travel purchases and travellers' commitment, despite both parties being fully aware of that contract may end after the next tender, would suggest that such an approach could prove even more fruitful in private sector contexts where longer cooperation is possible.

In the current study, we investigated how to enhance compliance in corporate travel service purchases at the managerial level in three-party cooperation. However, the strategies are realized at the operational level. In our example, the buyer, aided by its business travel agency and 
technology partners, has developed control practices to prevent non-compliance and put much effort into service development to commit end-users. In other words, the travellers have been made aware of the policy, and any barriers that would impede compliance with the policy have been removed. Upcoming research should include personal factors (Douglas \& Lubbe, 2009; Marshall et al., 1998), and the business travellers' perspective on travel purchase monitoring. In this way, one could investigate specific situations when travellers do not follow the policy, and could further specify the key elements in superior corporate travel service quality. Another future research suggestion is to investigate control and commitment in triads of tourism supply chains with a focus on controlling the suppliers, rather than the end-users. Here, findings from a more intensively researched field - manufacturing outsourcing - could be used as a starting point. Finally, the current study is a case study of travel procurement in a specific context. A similar study within the private sector could provide additional insights. 


\section{References}

Aguilera, A. (2008). Business travel and mobile workers. Transportation Research, Part A, 42(2), 1109-1116.

Akbaba, A. (2006). Measuring service quality in the hotel industry: A study in a business hotel in Turkey. International Journal of Hospitality Management, 25(2), 170-192.

Alamdari, F., \& Mason, K. (2006). The future of airline distribution. Journal of Air Transport Management, 12(3), 122-134.

Amaral, J., Billington, C., \& Tsay, A. (2004). Outsourcing production without losing control. Supply Chain Management Review, 8(8), 44-52.

American Express \& A.T. Kearney (2008). European expense management study. A study by the American Express Business Solutions Group and A.T. Kearney.

Anderson, R., Lewis, D., \& Parker, M. (1999). Another look at the efficiency of corporate travel management departments. Journal of Travel Research, 37(3), 267-272.

Andersson-Cederholm, E., \& Gyimóthy, S. (2010). The service triad: modelling dialectic tensions in service encounters. The Service Industries Journal, 30(2), 265-280.

Andreu, L., Aldás, J., Bigné, J. E., \& Mattila, A. (2010). An analysis of e-business adoption and its impact on relational quality in travel agency-supplier relationships. Tourism Management, 31(6), 777-787.

Angeles, R., \& Nath, R. (2007). Business-to-business e-procurement: success factors and challenges to implementation. Supply Chain Management: An International Journal, 12(2), 104-115.

Arnfalk, P., \& Kogg, B. (2003). Service transformation - managing a shift from business travel to virtual meetings. Journal of Cleaner Production, 11(8), 859-872.

Arthur, J. B. (1994). Effects of human resource systems on manufacturing performance and turnover. Academy of Management Journal, 37(3), 670-687.

Aulakh, P., \& Gencturk, E. (2000). International principal-agent relationships: Control, governance and performance. Industrial Marketing Management, 29(6), 521-538.

Bai, B., Brewer, K., Sammons, G., \& Swerdlow, P. (2006). Job Satisfaction, Organizational Commitment, and Internal Service Quality. Journal of Human Resources in Hospitality \& Tourism, 5(2), 37-41.

Barratt, M., Choi, T.Y., \& Li, M. (2011). Qualitative case studies in operations management: Trends, research outcomes, and future research implications. Journal of Operations Management, 29(4), 329-342.

Beaverstock, J.V., Derudder, B., Faulconbridge, J.R., \& Witlox, F. (2009). International business travel: some explorations, Geografiska Annaler: Series B, Human Geography, 91(3), 193202.

Bergbom, B., Vesala, H., Leppänen, A., Sainio, M., Mukala, K., \& Smolander, A. (2011). International work-related travel and its effects on the health and well-being of workers. The Finnish Work Environmental Fund. 
Bell, R., \& Morey, R. (1997). Are you in the book? Hotel attributes bundles and corporate travel departments. Cornell Hotel and Restaurant Administration Quarterly, 38(2), 55-62.

Berne, C., Garcia-Gonzales, M., \& Mugica, J. (2012). How ICT shifts the power balance of tourism distribution channels. Tourism Management, 33(1), 205-214.

Bhakoo, V., \& Choi, T. (2013). The iron cage exposed: Institutional pressures and heterogeneity across the healthcare supply chain. Journal of Operations Management, 31(6), 432-449.

Bigné, J.E., Aldás, J., \& Andreu, L. (2008). B2B services: IT adoption in travel agency supply chains. Journal of Services Marketing, 22(6), 454-464.

Bonner, J. (2005). The influence of formal controls on customer interactivity in new product development. Industrial Marketing Management, 34(1), 63-69.

Brandon-Jones, A., \& Carey, S. (2011). The impact of user-perceived e-procurement quality on system and contract compliance. International Journal of Operations \& Production Management, 31(3), $274-296$.

Buhalis, D., \& Law, R. (2008). Progress in information technology and tourism management: 20 years on and 10 years after the Internet - The state of eTourism research. Tourism Management, 29(4), 609-623.

Buhalis, D., \& Licata, M. (2002). The future eTourism intermediaries. Tourism Management, 23(3), 207-220.

Buhman, C., Kekre, S., \& Singhal, J. (2005). Interdisciplinary and interorganizational research: Establishing the science of enterprise networks. Production and Operations Management, 14(4), 493-514.

Choi, T., \& Kim, Y. (2008). Structural embeddedness and supplier management: A network perspective. Journal of Supply Chain Management, 44(4), 5-13.

Choi, T., \& Wu, Z. (2009). Triads in supply networks: Theorizing buyer-supplier-supplier relationships. Journal of Supply Chain Management, 45(1), 8-25.

Chu, R., \& Choi, T. (2000). An importance-performance analysis of hotel selection factors in the Hong Kong hotel industry: a comparison of business and leisure travelers. Tourism Management, 21(4), 363-377.

Cox, A., Watson, G., Lonsdale, C., \& Sanderson, J. (2004). Managing appropriately in power regimes: Relationship and performance management in 12 supply chain cases. Supply Chain Management: An International Journal, 9(5), 357-371.

Croom, S., \& Johnston, R. (2003). E-service: enhancing internal customer service through eprocurement. International Journal of Service Industry Management, 15(5), 539-55.

Cuganesan, R., \& Lee, R. (2006). Intra-organisational influences in procurement networks controls: The impacts of information technology. Management Accounting Research, 17(2), 141-170.

Decrop, A. (1999). Triangulation in qualitative tourism research. Tourism Management, 20(1), 157-161.

Denzin, N. K. (1978). The research act: A theoretical introduction to sociological methods. New York: McGraw-Hill. 
Douglas, A. (2008). A survey of corporate travellers in South Africa: Towards a model of travel policy compliance. Doctoral thesis. University of Pretoria, Faculty of Economic Management Sciences.

Douglas, A., \& Lubbe, B. (2006). Identifying value conflicts between stakeholders in corporate travel management by applying the soft value management model. Tourism Management, 27(6), 1130-1140.

Douglas, A., \& Lubbe, B. (2009). Violation of the corporate travel policy: An exploration of underlying value-related factors. Journal of Business Ethics, 84(1), 97-111.

Douglas, A., \& Lubbe, B. (2010). An empirical investigation into the role of personal-related factors on corporate travel policy compliance. Journal of Business Ethics, 92(3), 451-461.

Dubois, A., \& Gadde, L-E. (2002). Systematic combining: an abductive approach to case research. Journal of Business Research, 55(7), 553-560.

Dubois, A., \& Gadde, L-E. (2014). "Systematic combining”-A decade later. Journal of Business Research, 67(6), 1277-1284.

Dwyer, R., Schurr, P., \& Oh, S. (1987). Developing buyer-seller relationships. Journal of Marketing, 51(2), 11-27.

Dyer, J.H., \& Singh, H. (1998). The relational view: cooperative strategy and sources of interorganizational competitive advantage. Academy of Management Review, 23(4), 660-679.

Ellram, L.M. (1996). The use of the case study method in logistics research. Journal of Business Logistics, 17(2), 93-138.

Fredendall, L., Hopkins, C., \& Bhonsle, A. (2005). Purchasing's Internal Service Performance: Critical External and Internal Determinants. The Journal of Supply Chain Management, 41(2), 26-38.

Frost, F., \& Kumar, M. (2001). Service quality between internal customers and internal suppliers in an international airline. International Journal of Quality \& Reliability Management, 18(4), 371-386.

Ghauri, P., Grönhaug, K., \& Kristianslund, I. (2002). Research Methods in Business Studies; A Practical Guide, New York: Prentice Hall.

Glaser, B., \& Strauss, A. (1967). The discovery of grounded theory. Chicago: Aldine.

Granovetter, M. (1985). Economic action and social structure: the problem of embeddedness. American Journal of Sociology, 91(3), 481-510.

Gummesson, E. (2000). Qualitative Methods in Management Research. Sage Publications.

Gustafson, P. (2006). Work-related travel, gender and family obligations. Work, Employment \& Society, 20(3), 513-530.

Gustafson, P. (2012). Managing business travel: Developments and dilemmas in corporate travel management. Tourism Management, 33(2), 276-284.

Gustafson, P. (2013). Control and commitment in corporate travel management. Research in Transportation Business and Management, 9: 21-28. 
Hallowell, R., Schlesinger, L.A., \& Zornitsky, J. (1996). Internal service quality, customer satisfaction and job satisfaction: Linkages and implications for management. Human Resource Planning, 19(2), 21-32.

Han, S., Ham, S., Y., \& Baek, S. (2012). Passengers' perceptions of airline lounges: Importance of attributes that determine usage and service quality measurement. Tourism Management, 33(5), 1103-1111.

Harland, C., Brenchley, R., \& Walker, H. (2003). Risk in supply networks. Journal of Purchasing and Supply Management, 9(2), 51-62.

Harmancioglu, N. (2009). Portfolio of controls in outsourcing relationships for global new product development. Industrial Marketing Management, 38(4), 394-403.

Holma, A-M. (2010). Relationship Development in Business Triads - Case Studies in Corporate Travel Management. Journal of Business Market Management, 4(2), 73-90.

Holma, A-M. (2012). Interpersonal interaction in business triads - case studies in corporate travel purchasing. Journal of Purchasing \& Supply Management, 18(2), 101-112.

Holma, A-M. (2013). Adaptation in business contexts: Working triadic relationships, in Woodside, A. \& Baxter, R. (Edts.), Deep knowledge of B2B relationships within and across borders, Advances in Business Marketing \& Purchasing, 20 (pp. 94-119). Emerald Group Publishing Limited, UK.

Karjalainen, K., Kemppainen, K., \& van Raaij, E.K. (2009). Non-Compliant work behaviour in purchasing: An exploration of reasons behind maverick buying. Journal of Business Ethics, 85(2), 245-261.

Karjalainen, K., \& van Raaij, E. (2011). An empirical test of contributing factors to different forms of maverick buying. Journal of Purchasing \& Supply Management, 17(3), 185-197.

Kim, D., Kim. W., \& Han. J. (2007). A perceptual mapping of online travel agencies and preference attributes. Tourism Management, 28(2), 591-603.

Komppula, R. (2014). The role of individual entrepreneurs in the development of competitiveness for a rural tourism destination - A case study. Tourism Management, 40, February, 361-371.

Koopman, P. L. (1991). Between control and commitment: Management and change as the art of balancing. Leadership and Organizational Development Journal, 12(5), 3-7.

Kulp, S., Randall, T., Brandyberry, G., \& Potts, K. (2006). Using organizational control mechanisms to enhance procurement efficiency: how GlaxoSmithKline improved the effectiveness of e-procurement. Interfaces, 36(3), 209-19.

Large, R., \& König, T. (2009). A gap model of purchasing's internal service quality: Concept, case study and internal survey. Journal of Purchasing and Supply Management, 15(1), 2432.

Lepak, D.P., \& Snell, S.A. (1999). The human resource architecture: toward a theory of human capital allocation and development. Academy of Management Review, 24(1), 31-48.

Lepak, D.P., \& Snell, S.A. (2002). Examining the human resource architecture: the relationships among human capital, employment, and human resource configurations. Journal of Management, 28(4), 517-43. 
Li, M., \& Choi, T. (2009). Triads in services outsourcing: bridge, bridge decay and bridge transfer. Journal of Supply Chain Management, 45(3), 27-39.

Lindberg, N., \& Nordin, F. (2008). From products to services and back again: Towards a new service procurement logic. Industrial Marketing Management, 37(3), 292-300.

Llach, J., Marimon, F., del Mar Alonso-Almeida, M., \& Bernardo, M. (2013). Determinants of online booking loyalties for the purchasing of airline tickets. Tourism Management, 35, April, 23-31.

Lubbe, B., \& Douglas, A. (2009). Information and communication technologies in business and corporate travel management: An overview. in Information and Communication Technologies in Tourism 2009 proceedings of the international conference in Amsterdam, Netherlands, 2009 (pp. 455-466). Springer, Vienna.

March, R., \& Wilkinson, I. (2009). Conceptual tools for evaluating tourism partnerships. Tourism Management, 30(3), 455-462.

Marshall, G., Baker, J., \& Finn, D. (1998). Exploring internal customer service quality. Journal of Business \& Industrial Marketing, 13(4/5), 381-92.

Mason, K. (2002). Future trends in business travel decision making. Journal of Air Transport Management, 7(1), 47-69.

Mason, K., \& Gray, R. (1999). Stakeholders in a hybrid market: the example of air business passenger travel. The European Journal of Marketing, 33(9/10), 844-858.

Medina-Muñoz, R.D., Medina-Muñoz, D., \& García-Falcón, J. (2003). Understanding European tour operators' control on accommodation companies: an empirical evidence. Tourism Management, 24(29), 135-147.

Melián-González, S., \& Verano-Tacoronte, D. (2006). Is there more than one way to manage human resources in companies? Personnel Review, 36(1), 29-50.

Mena, C., Humphries, A., \& Choi, T. (2013). Toward a theory of multi-tier supply chain management. Journal of Supply Chain Management, 49(2), 58-77.

Millan, Á., \& Esteban, Á. (2004). Development of a multiple-item scale for measuring customer satisfaction in travel agencies services. Tourism Management, 25(5), 533-546.

Morrison, A., Ladig, K., \& Hsieh, S. (1994). Corporate travel in the USA, Characteristics of managers and departments. Tourism Management, 15(3), 177-184.

Myllärniemi, J., Vuori, V., Helander, N., Ilvonen, I., Okkonen, J., \&Virtanen, P. (2013). The role of an intermediator organisation in collaboration: how can an intermediator enhance value co-creation? International Journal of Applied Systemic Studies, 5(1/2), 3-21.

Narangajavana, Y., Garrigos-Simon, F. J., García, J. S., \& Forgas-Coll, S. (2014). Prices, prices and prices: A study in the airline sector. Tourism Management, 41(April), 28-42.

Niranjan, T.T., \& Metri, B.A. (2008). Client-vendor-end user triad: A service quality model for is/ites outsourcing. Journal of Services Research, 8(1), 123-138.

Nätti, S., Pekkarinen, S., Hartikka, A., \& Holappa, T. (2014). The intermediator role in value cocreation within a triadic business service relationship. Industrial Marketing Management, 43(6), 977-984. 
Pansiri, J. (2008). The effects of characteristics of partners on strategic alliance performance in the SME dominated travel sector. Tourism Management, 29(1), 101-115.

Patton, M. (1990). Qualitative evaluation and research methods. Newbury Park California. Sage 1990.

Phat, S., \& Milne, S. (2008). Network effects on cooperation in destination website development. Tourism Management, 29(6), 1131-1140

Ritter, T. (2000). A framework for analyzing interconnectedness of relationships. Industrial Marketing Management, 29(4), 317-326.

Rothschild, J. (1988) Corporate travel policy. Tourism Management, 9(1), 66-68.

Roy, S. (2003). OK You are now an approved supplier - but you still do not get orders: Understanding the case of the P-Card. Industrial Marketing Management, 32(7), 605-613.

Rossler, P., \& Hirsz, A. (1995). Purchasing's interaction with customers: The effects on customer satisfaction - a case study. International Journal of Purchasing and Materials Management, 32(1), 37-43.

Sachan, A., \& Datta, S. (2005). Review of supply chain management and logistics research. International Journal of Physical Distribution \& Logistics Management, 35(9), 664-705.

Seuring, S. (2008). Assessing the rigor of case study research in supply chain management. Supply Chain Management: An International Journal, 13(2), 128-137.

Shook, C., Adams, G., Ketchen, D., \& Craighead, C. (2009). Towards a theoretical toolbox for strategic sourcing. Supply Chain Management: An International Journal, 14(1), 3-10.

Sigala, M. (2007). Investigating the internet's impact on interfirm relations: Evidence from the business travel management distribution chain. Journal of Enterprise Information Management, 20(3), 335-355.

Stanley, L., \& Wisner, J. (2001). Service quality along the supply chain: implications for purchasing. Journal of Operations Management, 19(3), 287-306.

Topolšek, D., Mrnjavac, E., \& Kovačić, N. (2014). Integration of travel agencies with transport providers. Tourism Management Perspectives, 9, January, 14-23.

Van Iwaarden, J., \& van der Valk, W. (2013). Controlling outsourced service delivery: managing service quality in business service triads. Total Quality Management \& Business Excellence, 24(9), 1046-1061.

Van der Valk, W., \& van Iwaarden, J. (2011). Monitoring in service triads consisting of buyers, subcontractors and end customers. Journal of Purchasing and Supply Management, 17(3), 198-206.

Van Hoek, R. (2000). The purchasing and control of supplementary Third-Party Logistics services. Journal of Supply Chain Management, 46(4), 14-26.

Walton. R. A., (1985). From control to commitment in the workplace. Harvard Business Review, 63(2), 77-84.

Welch, D., Welch, L., \& Worm, V. (2007). The international business traveller: a neglected but strategic human resource. The International Journal of Human Resource Management, 18(2), 173-183. 
Wisner, J., \& Stanley, L. (1999). Internal Relationships and Activities Associated with High Levels of Purchasing. Journal of Supply Chain Management, 35(2), 25-32.

World Travel and Tourism Council (2011). Business Travel: A Catalyst for Economic Performance.

Wynstra, F., Axelsson, B., \& Van der Valk, W. (2006). An application-based classification to understand buyer-supplier interaction in business services. International Journal of Service Industry Management, 17(5), 474-496.

Xiao, H., \& Smith, S. (2006). Case studies in tourism research: A state-of-the-art analysis. Tourism Management, 27(5), 738-749.

Zhang, C., Cavusgil, S.T., \& Roath, A.S. (2003). Manufacturer governance of foreign distributor relationships: do relational norms enhance competitiveness in the export market? Journal of International Business Studies, 34(6), 550-566.

Zhang, X., Song, H., \& Huang, G.Q. (2009). Tourism supply chain management: A new research agenda. Tourism Management, 30(3), 345-358. 